Case Report

\title{
Barrett's Oesophagus in an Achalasia Patient: Immunological Analysis and Comparison with a Group of Achalasia Patients
}

\author{
Samuel Torres-Landa, ${ }^{1}$ Janette Furuzawa-Carballeda, ${ }^{2}$ Enrique Coss-Adame, ${ }^{3}$ \\ Miguel A. Valdovinos, ${ }^{3}$ Edgar Alejandro-Medrano, ${ }^{1}$ Bárbara Ramos-Ávalos, ${ }^{1}$ \\ Braulio Martínez-Benítez, ${ }^{4}$ and Gonzalo Torres-Villalobos ${ }^{1}$ \\ ${ }^{1}$ Department of Experimental Surgery, Instituto Nacional de Ciencias Médicas y Nutrición Salvador Zubirán, \\ Vasco de Quiroga No. 15, Colonia Belisario Domínguez Sección XVI, 14080 Mexico City, Mexico \\ ${ }^{2}$ Department of Immunology and Rheumatology, Instituto Nacional de Ciencias Médicas y Nutrición Salvador Zubirán, \\ Vasco de Quiroga No. 15, Colonia Belisario Domínguez Sección XVI, 14080 Mexico City, Mexico \\ ${ }^{3}$ Department of Gastroenterology, Instituto Nacional de Ciencias Médicas y Nutrición Salvador Zubirán, Vasco de Quiroga No. 15, \\ Colonia Belisario Domínguez Sección XVI, 14080 Mexico City, Mexico \\ ${ }^{4}$ Department of Pathology, Instituto Nacional de Ciencias Médicas y Nutrición Salvador Zubirán, Vasco de Quiroga No. 15, \\ Colonia Belisario Domínguez Sección XVI, 14080 Mexico City, Mexico
}

Correspondence should be addressed to Gonzalo Torres-Villalobos; torresvgm@yahoo.com.mx

Received 20 June 2016; Revised 26 July 2016; Accepted 2 August 2016

Academic Editor: Naohiko Koide

Copyright (C) 2016 Samuel Torres-Landa et al. This is an open access article distributed under the Creative Commons Attribution License, which permits unrestricted use, distribution, and reproduction in any medium, provided the original work is properly cited.

\begin{abstract}
The aim of the study was to characterize the presence of diverse CD4 and CD8 T cell subsets and regulatory cells in peripheral blood and lower oesophageal sphincter (LES) from a young patient with BE/achalasia without treatment versus achalasia group. In order to characterize the circulating cells in this patient, a cytometric analysis was performed. LES tissue was evaluated by double-immunostaining procedure. Five healthy blood donors, 5 type achalasia patients, and 5 oesophagus tissue samples (gastrooesophageal junction) from transplant donors were included as control groups. A conspicuous systemic inflammation was determined in BE/achalasia patient and achalasia versus healthy volunteer group. Nonetheless, a predominance of Th22, Th2, IFN$\alpha$-producing T cells, Tregs, Bregs, and pDCregs was observed in BE/achalasia patient versus achalasia group. A low percentage of Th1 subset in BE/achalasia versus achalasia group was determined. A noticeable increase in tissue of Th22, Th17, Th2, Tregs, Bregs, and pDCregs was observed in BE/achalasia versus achalasia group. Th1 subset was lower in the BE/achalasia patient versus achalasia group. This study suggests that inflammation is a possible factor in the pathogenesis of BE/achalasia. Further research needs to be performed to understand the specific cause of the correlation between $\mathrm{BE}$ and achalasia.
\end{abstract}

\section{Background}

Idiopathic achalasia is a primary oesophageal motor disorder characterized by the loss of oesophageal peristalsis and incomplete relaxation of the lower oesophageal sphincter (LES). The annual incidence and prevalence are 1 case per 100,000 and 10 in every 1,000,000 habitants, respectively [1]. Recent studies have suggested that achalasia has an important local and systemic autoimmune inflammatory response, with a high prevalence of specific autoantibodies against the myenteric plexus, and it has been associated with the presence of Herpes simplex virus type 1 [2]. Clinical manifestations include dysphagia, regurgitation, retrosternal chest pain, weight loss, and heartburn. Diagnosis is established by manometric studies and complementary tests like barium esophagram and esophagogastroduodenoscopy [1].

Barrett's oesophagus (BE) is a disease in which the normal distal squamous epithelial lining is replaced by metaplastic 
columnar epithelium that can be suspected by endoscopy and confirmed by histopathology [3]. BE/achalasia as cooccurring disease has been reported in up to $14 \%$ following treatment of achalasia [4]. However, in untreated patients this cooccurring finding is a rare phenomenon, and to our knowledge there are only 4 studies that have reported this association [5-8].

It is important to mention that the 4 patients previously reported were older ( $\geq 40$ years), the age being one of the major risk factors for $\mathrm{BE}$ due to the long natural history of the disease. In this case report we present the first report of immunological analysis of BE/achalasia in a young patient with no previous surgical or endoscopic treatment, diagnosed with BE.

\section{Case Presentation}

This case is of a 28-year-old man with a previous history of chronic hypertension, 12 years of tobacco consumption, and 7 years of alcohol consumption every 2 weeks, without any family history of BE. He was referred to our hospital after 1 year of progressive oesophageal dysphagia, associated with regurgitation, retrosternal chest pain, and weight loss of $7 \mathrm{~kg}$. Physical examination was unremarkable, and BMI was 28.37 at the moment of referral (BMI of 30.82 prior to the disease). A barium swallow showed oesophageal dilatation and bird beak sign (Figure 1(a)). A high resolution manometry (HRM) (Figure 1(b)) and panendoscopy were performed. The HRM showed an elevated IRP value of $31.2 \mathrm{mmHg}$, abnormal relaxation of lower oesophageal sphincter (LES), and aperistalsis with panoesophageal pressurization in $>20 \%$ of swallows, corresponding with type II achalasia. Hiatal hernia was not reported. Unexpectedly during the endoscopy procedure, irregular Z-line was seen with tong-like protrusions suspicious of $\mathrm{BE}$ that was classified as C $0 \mathrm{M} 1$ accordingly with the Prague Classification (Figures $1(\mathrm{c})$ and $1(\mathrm{~d})$ ). Biopsies of suspicious areas were taken and revised by two expert pathologists that reported metaplastic columnar epithelium (Barrett's oesophagus) without dysplasia (Figures $1(\mathrm{e})$ and $1(\mathrm{f}))$. The oesophageal $24 \mathrm{~h}$ impedance- $\mathrm{pH}$ monitoring showed normal acid exposure with $0.2 \%$ of $\mathrm{pH}<4$ and a DeMeester score of 1.1. The patient underwent Heller's myotomy with biopsy of the muscular layer of the oesophagus and Dor fundoplication in November 2015. Transsurgical endoscopy was negative for leakages. Within the first 24 hours the patient developed systemic inflammatory response syndrome. A water-soluble study was performed, which reported a possible leak from the myotomy site. CT scan reported pneumomediastinum without a visible leakage. $\mathrm{He}$ underwent a laparoscopic exploration without a visible site of leakage and negative cultures. The patient was treated without any other intervention, only with fasting, and was discharged without any further complications.

2.1. Ethical Considerations. The study was approved by the ethical medical committee in our institution (reference number 1522) and it was according to the principles expressed in the Declaration of Helsinki, 1989. Only patients who gave a written informed consent were recruited for this study. Each participant gave a written consent to publish their individual data.

\section{Discussion}

3.1. Barrett's Oesophagus and Achalasia. Although achalasia has been related to BE after surgical procedure [4], there is no clear explanation of the cause of this finding in a young patient before myotomy. Nonetheless, it is known that BE has been correlated to acid exposure due to gastric oesophageal reflux disease (GERD) [9]. One of the possibilities of this rare finding could be a chronic acid exposure secondary to GERD prior to the developing of achalasia. Another one could be that, in achalasia patients, food retention and its fermentation lower the $\mathrm{pH}$ due to lactic acid production, allowing chronic irritation against the oesophageal epithelium [9]. Although these two hypotheses cannot be confirmed, it is a fact that our patient had many of the risk factors (grade of evidence: II and IIa) for BE [3] including sex, heartburn, smoking, alcohol consumption, and $\mathrm{BMI}>30$.

\subsection{Immunophenotyping of Circulating Regulatory Cell and} CD4 Effector T Cell Subpopulations by Flow Cytometry. In a recent publication, our group [2] determined the peripheral blood immunophenotypes of different subtypes of achalasia. In order to characterize the peripheral blood compartment in this patient, we proceeded to follow the same methodology [2]. A group of 5 healthy blood donors and 5 type II achalasia patients, specifically sampled for this study, were included as control groups. A sample of venous blood $(10 \mathrm{~mL})$ was obtained from each subject. Peripheral blood mononuclear cells (PBMCs) were isolated by gradient centrifugation on Lymphoprep (Axis-Shield PoC AS, Oslo, Norway). Th22 ( $\left.\mathrm{CD}^{+} / \mathrm{CD}^{+} / \mathrm{CD} 161^{-} / \mathrm{IL}_{-} 22^{+}\right)$, Th17 $\left(\mathrm{CD}^{+} / \mathrm{CD}^{+} / \mathrm{CD} 161^{+} / \mathrm{IL}-17 \mathrm{~A}^{+}\right), \mathrm{Th} 2\left(\mathrm{CD}^{+} / \mathrm{CD}^{+} / \mathrm{CD} 5^{+} /\right.$ IL- $\left.4^{+}\right)$, Th1 $\left(\mathrm{CD}^{+} / \mathrm{CD} 4^{+} / \mathrm{CD} 25^{+} / \mathrm{IFN}-\gamma^{+}\right)$, IFN- $\alpha$-producing $\mathrm{T}$ cells $\left(\mathrm{CD}^{+} / \mathrm{CD} 4^{+} / \mathrm{CD} 25^{+} / \mathrm{IFN}-\alpha^{+}\right.$and $\mathrm{CD}^{+} / \mathrm{CD}^{+} /$ $\left.\mathrm{CD} 28^{+} / \mathrm{IFN}-\alpha^{+}\right)$, regulatory $\mathrm{T}$ cells $\left(\mathrm{CD}^{+} / \mathrm{CD} 4^{+} / \mathrm{CD} 25^{\mathrm{hi}} /\right.$ $\mathrm{Foxp}^{+}, \mathrm{CD}^{+} / \mathrm{CD} 4^{+} / \mathrm{CD} 25^{\mathrm{hi}} / \mathrm{IL}_{-} 35^{+}, \mathrm{CD}^{+} / \mathrm{CD}^{+} / \mathrm{CD} 28^{-} /$ $\mathrm{Foxp}^{+}$, and $\mathrm{CD}^{+} / \mathrm{CD}^{+} / \mathrm{CD} 28^{-} / \mathrm{IL}-35^{+}$), regulatory B cells $\left(\mathrm{CD}^{+} / \mathrm{CD} 19^{+} / \mathrm{CD} 38^{\mathrm{hi}} / \mathrm{IL}-10^{+}\right.$and $\mathrm{CD}^{+} / \mathrm{CD} 19^{+} / \mathrm{CD} 38^{\mathrm{hi}} / \mathrm{IL}-$ $35^{+}$), and regulatory plasmacytoid dendritic cells (pDCs; $\mathrm{CD}_{2} 3^{\mathrm{hi}} / \mathrm{CD} 196^{+} / \mathrm{IDO}^{+}$) were determined. In the cytometric analysis, a conspicuous systemic inflammation was determined in BE/achalasia patient and achalasia group compared with healthy volunteer group (Table 1). Nonetheless, a predominance of Th22, Th2, IFN- $\alpha$-producing T cells, Tregs, Bregs, and pDCregs was observed in BE/achalasia patient compared with achalasia group. In contrast a low percentage of Th1 subset in BE/achalasia versus achalasia patient group was determined (Table 1). Th17 profile was similar in our BE/achalasia patient compared with achalasia group (Table 1).

3.3. Characterization of Tissue Regulatory Cell and CD4 Effector Cell Subsets by Immunohistochemistry. In order to determine the characteristics of the cellular infiltrate, 


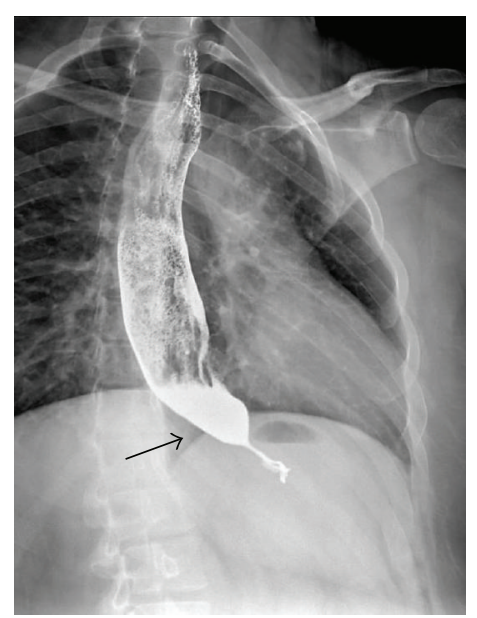

(a)

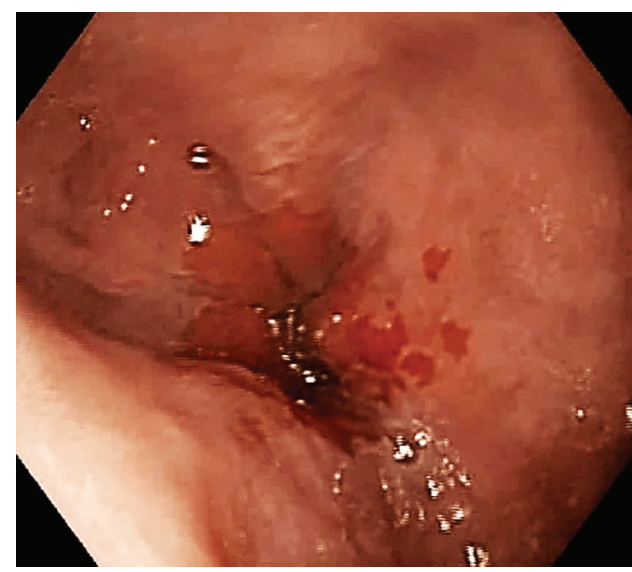

(c)

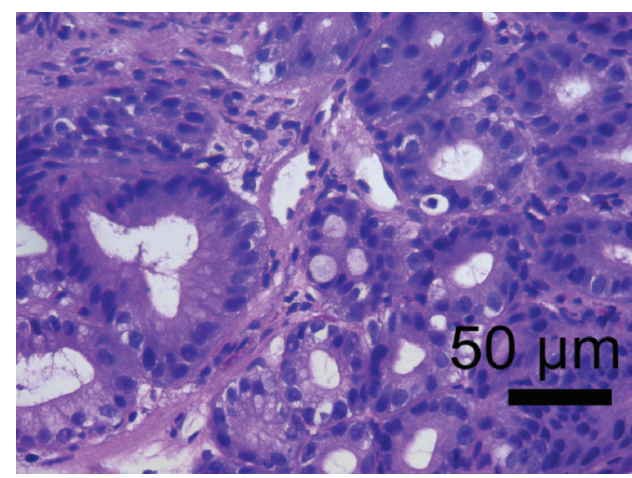

(e)

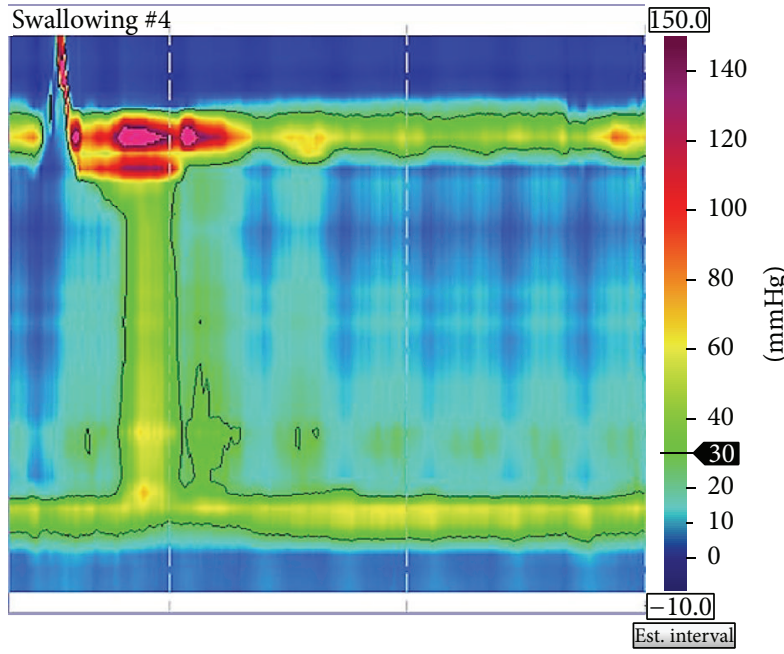

(b)

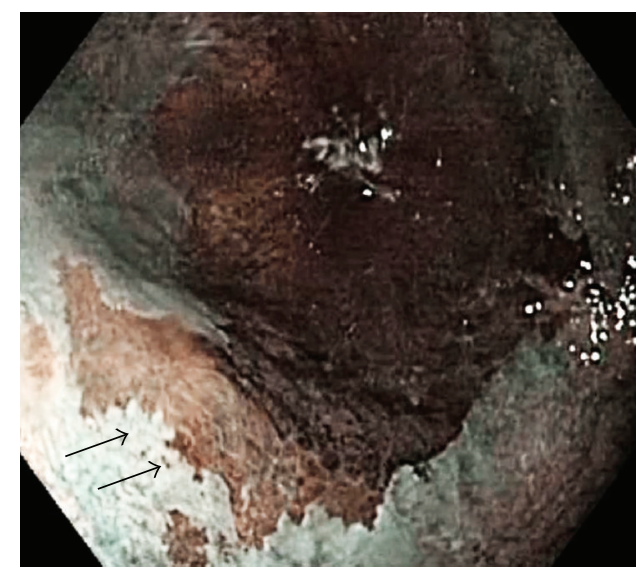

(d)

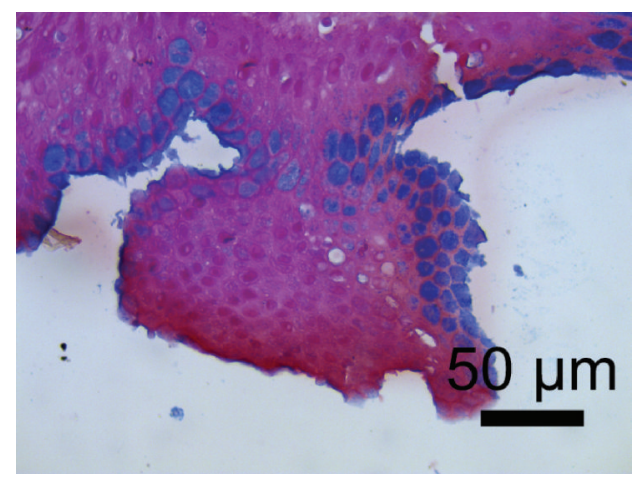

(f)

FIGURE 1: (a) Barium oesophagram that shows dilatation and bird beak sign (arrow). (b) High resolution manometry that shows abnormal relaxation of lower oesophageal sphincter and aperistalsis with panesophageal pressurization in $40 \%$ of swallows, corresponding with type II achalasia. (c) Upper endoscopy shows dilated esophagus with mucosal changes consistent with C0 M1 Barrett's oesophagus. (d) Arrows indicate margins of "tongues" of Barrett's metaplasia. (e) Metaplastic columnar epithelium. (f) Photomicrograph that highlights the metaplasia. Original magnification in high field power (100x). 
TABLE 1: Analysis of peripheral blood and tissue immunophenotypes in the present case compared to 5 achalasia patients and 5 control subjects.

\begin{tabular}{|c|c|c|c|}
\hline & $\begin{array}{l}\text { Healthy donors } \\
\quad(n=5)\end{array}$ & $\begin{array}{c}\text { Type II achalasia } \\
(n=5)\end{array}$ & Patient \\
\hline & & Blood & \\
\hline \multicolumn{4}{|c|}{ Peripheral blood immunophenotypes } \\
\hline \multicolumn{4}{|c|}{$\mathrm{CD}^{+} / \mathrm{CD} 4^{+} / \mathrm{CD} 161^{-} / \mathrm{IL}-22^{+}(\%)$} \\
\hline Mean \pm SD & $1.95 \pm 0.53$ & $6.58 \pm 2.56$ & \multirow{3}{*}{7.72} \\
\hline Median & 1.79 & 4.90 & \\
\hline Range & $1.39-2.55$ & $2.79-16.70$ & \\
\hline \multicolumn{4}{|c|}{$\mathrm{CD3}^{+} / \mathrm{CD}^{+} / \mathrm{CD} 161^{+} / \mathrm{IL}-17 \mathrm{~A}^{+}$(\%) } \\
\hline Mean \pm SD & $1.96 \pm 0.80$ & $5.62 \pm 1.73$ & \multirow{3}{*}{5.42} \\
\hline Median & 1.64 & 4.95 & \\
\hline Range & $1.40-3.35$ & $2.72-12.30$ & \\
\hline \multicolumn{4}{|c|}{$\mathrm{CD}^{+} / \mathrm{CD}^{+} / \mathrm{CD} 25^{+} / \mathrm{IL}-4^{+}(\%)$} \\
\hline Mean \pm SD & $1.44 \pm 0.65$ & $3.23 \pm 0.70$ & \multirow{3}{*}{4.19} \\
\hline Median & 1.36 & 3.76 & \\
\hline Range & $0.52-2.09$ & $1.55-4.99$ & \\
\hline \multicolumn{4}{|c|}{$\mathrm{CD}^{+} / \mathrm{CD}^{+} / \mathrm{CD} 25^{+} / \mathrm{IFN}-\gamma^{+}(\%)$} \\
\hline Mean \pm SD & $1.76 \pm 0.97$ & $4.18 \pm 1.31$ & \multirow{3}{*}{3.6} \\
\hline Median & 1.91 & 3.43 & \\
\hline Range & $0.29-2.87$ & $2.15-9.30$ & \\
\hline \multicolumn{4}{|c|}{$\mathrm{CD3}^{+} / \mathrm{CD}^{+} / \mathrm{CD} 25^{+} / \mathrm{IFN}-\alpha^{+}(\%)$} \\
\hline Mean \pm SD & $2.26 \pm 1.2$ & $4.47 \pm 0.85$ & \multirow{3}{*}{5.08} \\
\hline Median & 1.81 & 3.73 & \\
\hline Range & $1.31-4.35$ & $2.11-6.80$ & \\
\hline \multicolumn{4}{|c|}{$\mathrm{CD}^{+} / \mathrm{CD}^{+} / \mathrm{CD} 28^{+} / \mathrm{IFN}-\alpha^{+}(\%)$} \\
\hline Mean \pm SD & $3.05 \pm 1.97$ & $3.99 \pm 0.47$ & \multirow{3}{*}{5.87} \\
\hline Median & 2.82 & 4.28 & \\
\hline Range & $1.48-6.39$ & $2.54-5.27$ & \\
\hline \multicolumn{4}{|c|}{$\mathrm{CD}^{+} / \mathrm{CD} 4^{+} / \mathrm{CD} 25^{h i} / \mathrm{Foxp}^{+}$(\%) } \\
\hline Mean \pm SD & $5.16 \pm 0.78$ & $7.21 \pm 0.45$ & \multirow{3}{*}{10.1} \\
\hline Median & 5.05 & 7.32 & \\
\hline Range & $4.00-6.03$ & $5.64-8.35$ & \\
\hline \multicolumn{4}{|c|}{$\mathrm{CD}^{+} / \mathrm{CD}^{+} / \mathrm{CD} 25^{h i} / \mathrm{IL}-35^{+}$(\%) } \\
\hline Mean \pm SD & $3.60 \pm 0.98$ & $4.08 \pm 0.44$ & \multirow{3}{*}{9.96} \\
\hline Median & 3.64 & 4.28 & \\
\hline Range & $2.50-5.11$ & $2.39-4.88$ & \\
\hline \multicolumn{4}{|c|}{$\mathrm{CD}^{+} / \mathrm{CD}^{+} / \mathrm{CD} 28^{-} / \mathrm{Foxp}^{+}$(\%) } \\
\hline Mean \pm SD & $3.82 \pm 0.71$ & $5.39 \pm 0.28$ & \multirow{3}{*}{6.72} \\
\hline Median & 3.95 & 5.46 & \\
\hline Range & $3.01-4.77$ & $4.42-6.06$ & \\
\hline \multicolumn{4}{|c|}{$\mathrm{CD}^{+} / \mathrm{CD}^{+} / \mathrm{CD} 28^{-} / \mathrm{IL}-35^{+}$(\%) } \\
\hline Mean \pm SD & $3.37 \pm 0.77$ & $4.53 \pm 1.28$ & \\
\hline Median & 3.69 & 3.02 & 12.4 \\
\hline Range & $2.19-4.01$ & $2.12-9.09$ & \\
\hline $\mathrm{CD}^{+} / \mathrm{CD} 19^{+} / \mathrm{C}$ & & & \\
\hline Mean \pm SD & $6.27 \pm 1.07$ & $6.99 \pm 0.58$ & \\
\hline Median & 6.08 & 6.50 & 14.1 \\
\hline Range & $5.07-7.81$ & $4.88-8.09$ & \\
\hline $\mathrm{CD}^{+} / \mathrm{CD} 19^{+} / \mathrm{C}$ & & & \\
\hline Mean \pm SD & $5.95 \pm 0.45$ & $4.31 \pm 0.89$ & \\
\hline Median & 5.88 & 3.90 & 19.2 \\
\hline Range & $5.58-6.70$ & $2.20-7.60$ & \\
\hline $\mathrm{CD} 23^{+} / \mathrm{CD} 196$ & & & \\
\hline Mean \pm SD & $11.84 \pm 1.36$ & $16.82 \pm 1.66$ & \\
\hline Median & 11.50 & 18.70 & 21.2 \\
\hline Range & $10.30-14.00$ & $10.80-19.47$ & \\
\hline
\end{tabular}


TABLE 1: Continued.

\begin{tabular}{|c|c|c|c|}
\hline & $\begin{array}{l}\text { Healthy donors } \\
\quad(n=5)\end{array}$ & $\begin{array}{l}\text { Type II achalasia } \\
\quad(n=5)\end{array}$ & Patient \\
\hline & & Tissue & \\
\hline \multicolumn{4}{|c|}{ Tissue immunophenotypes } \\
\hline \multicolumn{4}{|c|}{ IL-22-expressing cells (\%) } \\
\hline Mean \pm SD & $3.83 \pm 1.83$ & $17.83 \pm 1.47$ & \multirow{3}{*}{23.5} \\
\hline Median & 4.00 & 17.50 & \\
\hline Range & $2.00-7.00$ & $16.00-20.00$ & \\
\hline \multicolumn{4}{|c|}{ IL-17A-expressing CD4 T cells (\%) } \\
\hline Mean \pm SD & $1.00 \pm 0.68$ & $8.33 \pm 1.75$ & \multirow{3}{*}{17.00} \\
\hline Median & 0.00 & 7.50 & \\
\hline Range & $0.00-4.00$ & $7.00-11.00$ & \\
\hline \multicolumn{4}{|c|}{ IL-4-expressing CD4 T cells (\%) } \\
\hline Mean $\pm \mathrm{SD}$ & $1.33 \pm 0.33$ & $6.33 \pm 0.75$ & \multirow{3}{*}{14.00} \\
\hline Median & 1.50 & 7.00 & \\
\hline Range & $0.00-2.00$ & $4.00-9.00$ & \\
\hline \multicolumn{4}{|c|}{ IFN- $\gamma$-expressing CD4 T cells (\%) } \\
\hline Mean \pm SD & $1.50 \pm 0.67$ & $15.0 \pm 1.27$ & \multirow{3}{*}{10.00} \\
\hline Median & 1.00 & 14.5 & \\
\hline Range & $0.00-4.00$ & $14.00-17.00$ & \\
\hline \multicolumn{4}{|c|}{ Foxp3-expressing CD25 T cells (\%) } \\
\hline Mean \pm SD & $4.33 \pm 0.33$ & $7.83 \pm 0.48$ & \multirow{3}{*}{11.50} \\
\hline Median & 4.50 & 8.00 & \\
\hline Range & $3.00-5.00$ & $6.00-9.00$ & \\
\hline \multicolumn{4}{|c|}{ IL-10-expressing CD20 B cells (\%) } \\
\hline Mean \pm SD & $1.83 \pm 1.31$ & $5.33 \pm 0.49$ & \multirow{3}{*}{7.5} \\
\hline Median & 2.00 & 5.50 & \\
\hline Range & $1.00-3.00$ & $4.00-7.00$ & \\
\hline \multicolumn{4}{|c|}{ IDO-expressing CD123 cells (\%) } \\
\hline Mean \pm SD & $3.67 \pm 0.82$ & $6.67 \pm 0.33$ & \multirow{3}{*}{8.5} \\
\hline Median & 3.50 & 6.50 & \\
\hline Range & $3.00-5.00$ & $6.00-8.00$ & \\
\hline
\end{tabular}

regulatory cells, and interleukin expression present at the lower oesophageal muscle, tissue was stained with specific monoclonal antibodies. Five type II achalasia patients and 5 oesophagus tissue samples (gastrooesophageal junction) from transplant donors were included as a control tissue (Figure 2). Thus, the subpopulation of IL-22producing cells, $\mathrm{CD} 4^{+} / \mathrm{IL}-17 \mathrm{~A}^{+}-, \mathrm{CD} 4^{+} / \mathrm{IL}-4^{+}-, \mathrm{CD} 4^{+} / \mathrm{IFN}-$ $\gamma^{+}$-expressing $\mathrm{T}$ cells, $\mathrm{CD} 25^{+} / \mathrm{Foxp}^{+}$regulatory $\mathrm{T}$ cells, $\mathrm{CD} 23^{+} / \mathrm{IDO}^{+} \mathrm{pDCs}$, and $\mathrm{CD} 20^{+} / \mathrm{IL}-10^{+}$-producing B cells was determined with a simultaneous detection using a Multiview (mouse-HRP/rabbit-AP) immunohistochemistry kit (Enzo Life Sciences, Inc., Farmingdale, NY, USA) [2]. Immunohistochemistry findings showed greater amounts of inflammatory and regulatory cells in BE/achalasia patient and achalasia group compared with control group (Table 1). On the other hand, a noticeable increase in Th22, Th17, Th2, Tregs, Bregs, and pDCregs was observed in BE/achalasia compared to achalasia patient group (Table 1, Figure 2). Th1 subset was lower in the $\mathrm{BE} /$ achalasia patient compared with the achalasia group (Table 1, Figure 2).

3.4. Appropriate Treatment and Surveillance. One of the main concerns regarding this patient condition is the posterior risk of developing dysplasia. It has been reported that, due to the high acid exposure presented after Heller's myotomy, a partial fundoplication is now recommended to reduce gastrooesophageal reflux [10]. Although Dor/Toupet fundoplication is more commonly performed on these patients, a significant difference between both partial fundoplications acting as acid barrier has not been reported [11]. The patient underwent an appropriate treatment for his condition although a close surveillance with symptoms, acid exposure, and upper endoscopy could be needed.

Our data suggest that patients with BE/achalasia could have higher inflammation and a higher risk of oesophageal perforation compared with achalasia patients. Moreover, inflammation is considered as the connection of Barrett's carcinogenesis. Key mediators of inflammation in $\mathrm{BE}$ have been previously described and include proinflammatory cytokines, chemokines, reactive oxygen species, prostaglandins, and microRNAs [12]. Moons et al. have also demonstrated an increase of Th2 effector cells in BE tissue [13]. Moreover, in serum from BE patients a strong positive association with high level of IL-12p70, IL-8, and leptin and a negative association with IL- 10 and IL- $1 \beta$ have been determined. Meanwhile there were no differences between 

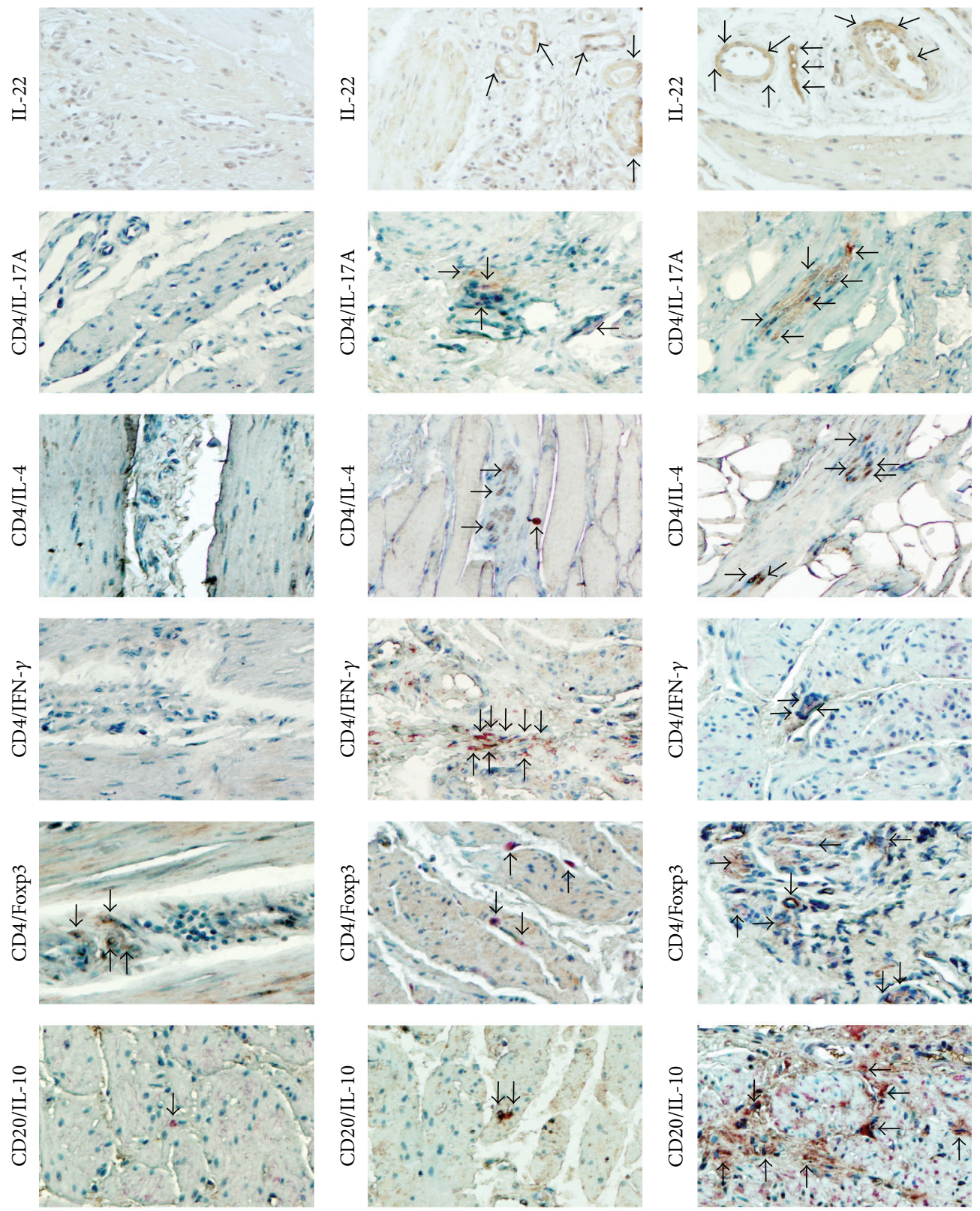

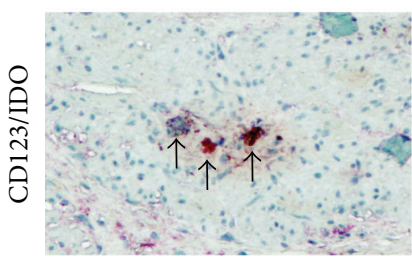

(a)

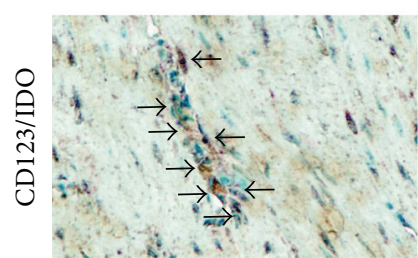

(b)

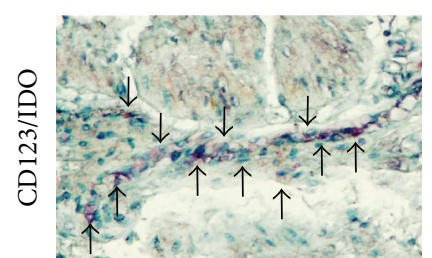

(c)

FIgURE 2: CD4 effector T cells and regulatory cells in lower oesophageal sphincter. Representative photomicrograph from control (healthy donor, (a)), type II achalasia (b), and Barrett's oesophagus/type II achalasia patient (c). Arrows depict immunoreactive cells. Original magnification was $\times 320$.

serum controls and BE patients in levels of IFN- $\gamma$, TNF- $\alpha$, adiponectin, or insulin [14]. In the BE/achalasia patient we have shown that Th22, Th17, and Th2 but not Th1 profile interplay at tissue and peripheral cells in BE/achalasia patient.
In addition to the presence of proinflammatory cells there is an increase of Treg, IL-10-producing B cell, and pDCreg cell percentage suggesting that proinflammatory and regulatory balance favours the former with the failure of the latter 
in maintaining homeostasis and conducting more vigorous tissue damage. However this study suggests that inflammation is a possible factor in the pathogenesis of BE/achalasia with the concomitant use of immunosuppressive drugs as probable future treatment for this pathology. It is relevant to highlight the need for a close follow-up to prevent further complications.

\section{Conclusion}

In conclusion, our preliminary results deserve to be studied in depth to appraise the clinical relevance of these findings. It is also necessary to clarify whether the association of $\mathrm{BE}$ and achalasia is an epiphenomenon or might share common pathophysiological pathways.

$\begin{array}{ll}\text { Abbreviations } \\ \text { AP: } & \text { Alkaline phosphatase } \\ \text { BE: } & \text { Barrett's oesophagus } \\ \text { BMI: } & \text { Body Mass Index } \\ \text { GERD: } & \text { Gastric oesophageal reflux disease } \\ \text { HRM: } & \text { High resolution manometry } \\ \text { HRP: } & \text { Horseradish peroxidase } \\ \text { IFN: } & \text { Interferon } \\ \text { IL: } & \text { Interleukin } \\ \text { LES: } & \text { Lower oesophageal sphincter } \\ \text { PBMCs: } & \text { Peripheral blood mononuclear cells } \\ \text { pDCreg: } & \text { Regulatory plasmacytoid dendritic cell } \\ \text { Th: } & \text { T helper cell } \\ \text { TNF: } & \text { Tumour necrosis factor } \\ \text { Treg: } & \text { Regulatory T cell. }\end{array}$

\section{Ethical Approval}

The study was approved by the ethical medical committee in the authors' institution (reference number 1522) and it was according to the principles expressed in the Declaration of Helsinki, 1989.

\section{Consent}

Each participant gave a written consent to publish their individual data (only patients who gave a written informed consent were recruited for this study).

\section{Competing Interests}

None of the authors have any competing interests.

\section{Authors' Contributions}

Samuel Torres-Landa and Janette Furuzawa-Carballeda are responsible for study concept and design, acquisition of data, analysis and interpretation of data, drafting of the paper, critical revision of the paper for important intellectual content, technical support, and obtained funding. Enrique CossAdame, Miguel A. Valdovinos, and Bárbara Ramos-Ávalos performed acquisition of data, analysis and interpretation of data, and critical revision of the paper for important intellectual content. Edgar Alejandro-Medrano and Braulio Martínez-Benítez contributed to acquisition of data, analysis, interpretation of data, and technical and material support. Gonzalo Torres-Villalobos is responsible for study concept and design, acquisition of data, analysis and interpretation of data, drafting of the paper, critical revision of the paper for important intellectual content, statistical analysis, technical support, and study supervision and obtained funding. Samuel Torres-Landa and Janette Furuzawa-Carballeda contributed equally to this work.

\section{Acknowledgments}

This work was supported by grant from CONACyT (SALUD2014-1-233760).

\section{References}

[1] M. F. Vaezi, J. E. Pandolfino, and M. F. Vela, "ACG clinical guideline: diagnosis and management of achalasia," American Journal of Gastroenterology, vol. 108, no. 8, pp. 1238-1249, 2013.

[2] J. Furuzawa-Carballeda, D. Aguilar-León, A. GamboaDomínguez et al., "Achalasia-an autoimmune inflammatory disease: a cross-sectional study," Journal of Immunology Research, vol. 2015, Article ID 729217, 18 pages, 2015.

[3] R. C. Fitzgerald, M. di Pietro, K. Ragunath et al., "British Society of Gastroenterology guidelines on the diagnosis and management of Barrett's oesophagus," Gut, vol. 63, no. 1, pp. 7-42, 2014.

[4] K. Ravi, D. M. Geno, and D. A. Katzka, "Esophageal cancer screening in achalasia: is there a consensus?" Diseases of the Esophagus, vol. 28, no. 3, pp. 299-304, 2016.

[5] D. J. Sprung and S. P. Gibb, "Barrett's esophagus in a patient with achalasia," American Journal of Gastroenterology, vol. 80, no. 5, pp. 330-333, 1985.

[6] M. Halland and J. A. Alexander, "A case of esophageal 'double jeopardy," Gastroenterology, vol. 148, pp. 711-712, 2015.

[7] J.-P. Guo, P. B. Gilman, R. M. Thomas, R. S. Fisher, and H. P. Parkman, "Barrett's esophagus and achalasia," Journal of Clinical Gastroenterology, vol. 34, no. 4, pp. 439-443, 2002.

[8] P. Cantù, D. Savojardo, D. Baldoli, L. Bonavina, and R. Penagini, "Barrett's esophagus in untreated achalasia: 'Guess who's coming to dinner'first," Diseases of the Esophagus, vol. 21, no. 5, p. 473, 2008.

[9] H. L. Smart, P. N. Foster, and D. F. Evans, "Twenty four hour oesophaeal acidity in achalasia before and after pneumatic dilatation," Gut, vol. 28, no. 7, pp. 883-887, 1987.

[10] W. O. Richards, A. Torquati, M. D. Holzman et al., "Heller myotomy versus heller myotomy with dor fundoplication for achalasia: a prospective randomized double-blind clinical trial," Annals of Surgery, vol. 240, no. 3, pp. 405-415, 2004.

[11] A. Rawlings, N. J. Soper, B. Oelschlager et al., "Laparoscopic Dor versus Toupet fundoplication following Heller myotomy for achalasia: results of a multicenter, prospective, randomizedcontrolled trial," Surgical Endoscopy, vol. 26, no. 1, pp. 18-26, 2012.

[12] A. Poehlmann, D. Kuester, P. Malfertheiner, T. Guenther, and A. Roessner, "Inflammation and Barrett's carcinogenesis," Pathology Research and Practice, vol. 208, no. 5, pp. 269-280, 2012. 
[13] L. M. G. Moons, J. G. Kusters, E. Bultman et al., "Barrett's oesophagus is characterized by a predominantly humoral inflammatory response," The Journal of Pathology, vol. 207, no. 3, pp. 269-276, 2005.

[14] J. M. Garcia, A. E. Splenser, J. Kramer et al., "Circulating inflammatory cytokines and adipokines are associated with increased risk of Barrett's esophagus: a case-control study," Clinical Gastroenterology and Hepatology, vol. 12, no. 2, pp. 229.e3-238.e3, 2014. 


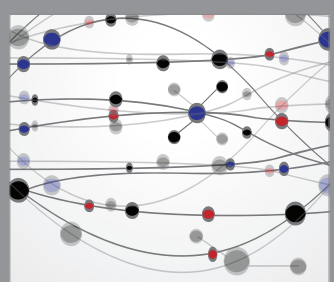

The Scientific World Journal
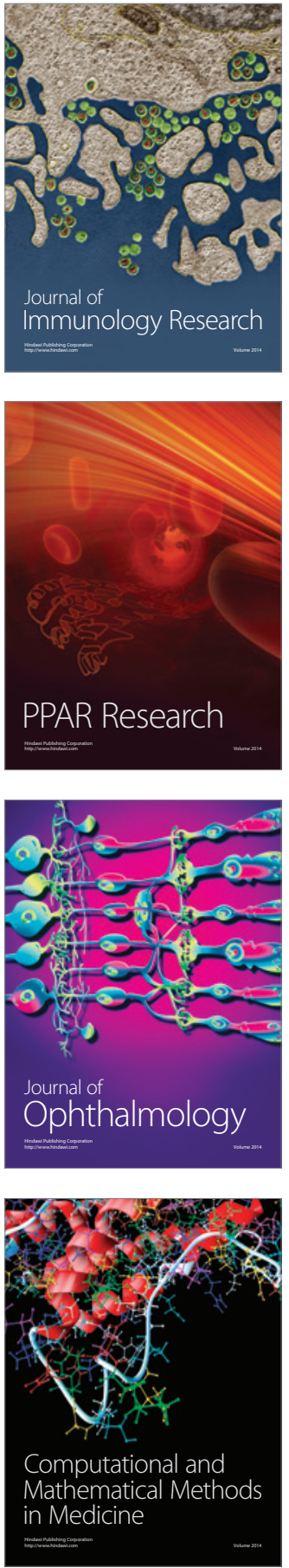

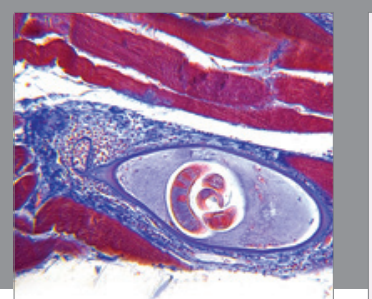

Gastroenterology Research and Practice

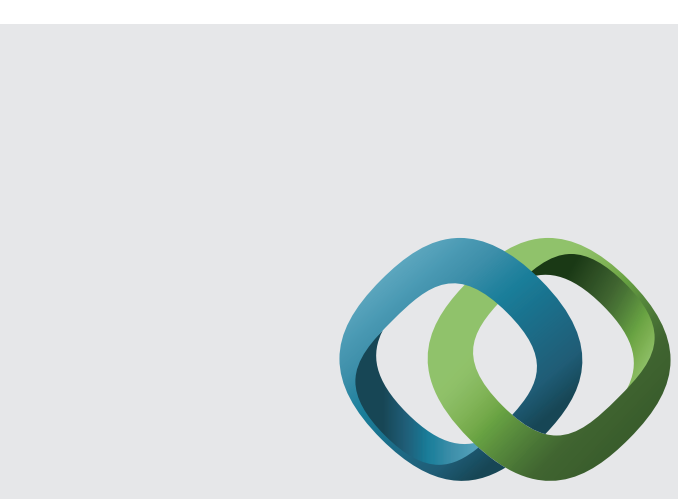

\section{Hindawi}

Submit your manuscripts at

http://www.hindawi.com
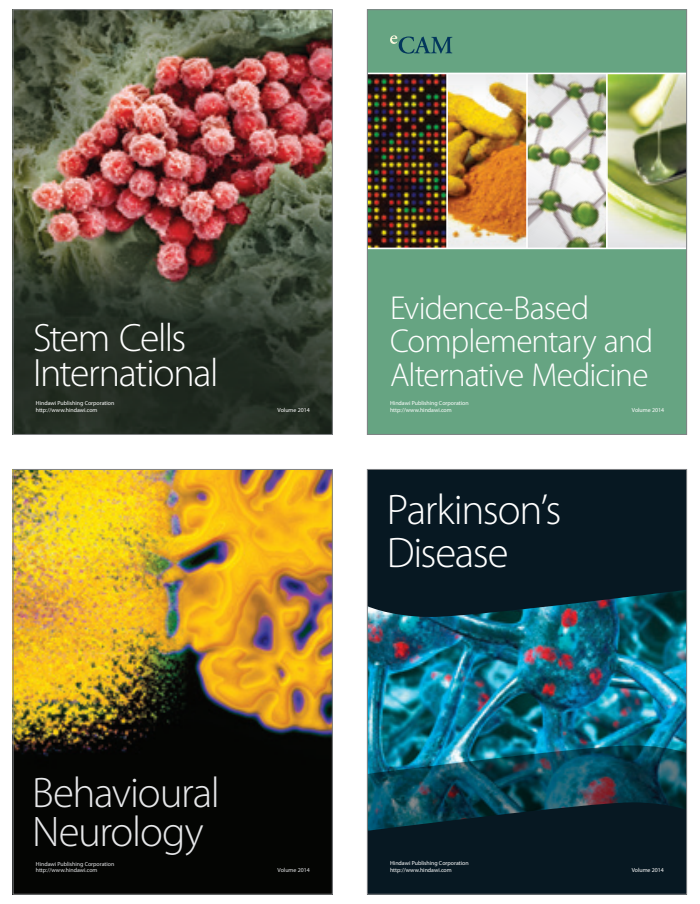
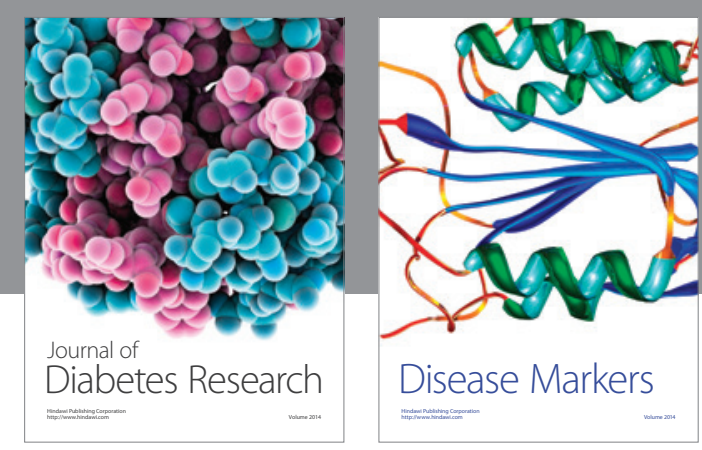

Disease Markers
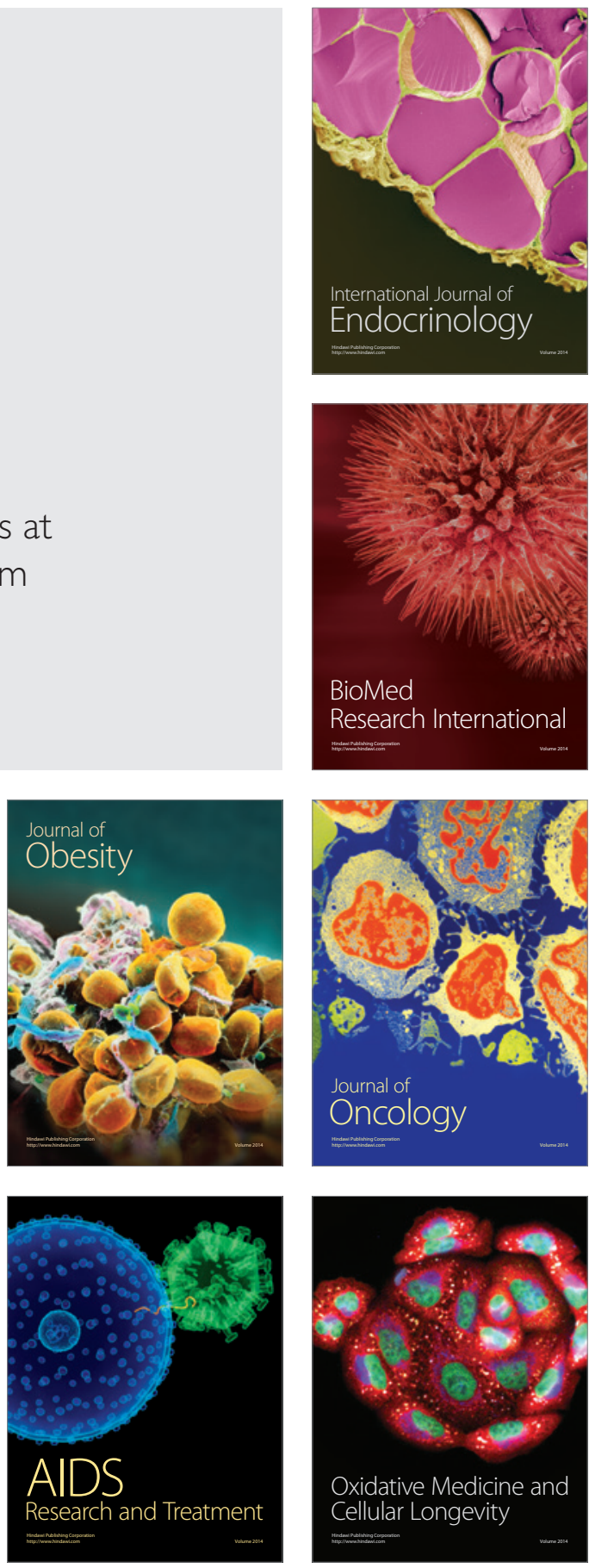